\title{
EVALUASI KESESUAIAN LAHAN UNTUK PERMUKIMAN DI KECAMATAN SUNGAI PUA KABUPATEN AGAM
}

\author{
Defrina Bahar \\ Program Studi Geografi \\ Fakutas Ilmu Sosial, Universitas Negeri Padang \\ Email: defrinabahar@ymail.com
}

\begin{abstract}
Abstrak
Penelitian ini bertujuan untuk mengetahui karakteristik lahan dan mengetahui tingkat kesesuaian lahan untuk permukiman di Kecamatan Sungai Pua. Jenis penelitian ini adalah deskriptif dengan pendekatan kuantitatif, metode analisa penelitian ini adalah scoring. Pengambilan sampel dalam penelitian ini dengan cara purpose sampling, yakni pada satuan lahan yang berada pada lereng I dan II. Berdasarkan peta satuan lahan Kecamatan Sungai terdapat 22 satuan lahan. Melalui hasil lapangan evaluasi kesesuaian lahan untuk permukiman di Kecamatan Sungai Pua terdapat tiga kriteria kesesuaian lahan yakni cukup sesuai, sangat sesuai dan tidak sesuai permanen. Kriteria cukup sesuai terdapat pada satuan lahan V4.I.Lad.And.Qast,

V4.I.Lad.Kam.Qast, V4.I.Sw.Kam.Qama, V4.II.HLKS.And.Qast, V4.II.Kbn.And.Qama, V4.II.Lad.And.Qast, V4.II.Pm.And.Qama. Kriteria sangat sesuai terdapat pada satuan lahan V4.I.Kbn.And.Qama, V4.I.Kbn.Kam.Qama, V4.I.Pm.And.Qama, V4.I.Pm.Kam.Qama, V4.I.Pm.Kam.Qast, V4.I.Sw.And.Qama. Kriteria tidak sesuai permanen terdapat pada satuan lahan V1.V.HLKP.And.Qama,V1.V.HLKP.And.Qast, V2.IVHLKP.And.Qama, V2.IV.HLKP.And.Qast, V2.IV.HLKS.And.Qast, V3III.HLKP.And.Qama, V V3.III.HLKS.And.Qama, V3.III.HLKS.And.Qast, V4.II.HLKS.And.Qama. Sebaran spasial kesesuaian lahan untuk kriteria tidak sesuai permanen tersebar pada seluruh kanagarian pada Kecamatan Sungai Pua kecuali pada Kanagarian Batagak. Kesesuaian lahan kriteria sangat sesuai dan cukup sesuai tersebar pada seluruh kanagarian di Kecamatan Sungai Pua.
\end{abstract}

\section{Kata Kunci: Kesesuaian, Evaluasi, Permukiman}

\begin{abstract}
This study aims to determine the characteristics of the land and determine the level of land suitability for settlements in the District River Pua. The type of this research is descriptive with quantitative approach, the method of analysis of this research is scoring. Sampling in this study by purposive sampling, ie on units of land located on the slopes I and II. Based on the map of land units River District there are 22 units of land. Through the field evaluation of land suitability for settlements in Sungai Pua subdistrict, there are three land suitability criteria that are quite appropriate, very suitable and not permanently suitable. Sufficient criteria are available in units of land V4.I.Lad.And.Qast, V4.I.Lad.Kam.Qast, V4.I.Sw.Kam.Qama, V4.II.HLKS.And.Qast, V4.II .Kbn.And.Qama, V4.II.Lad.And.Qast, V4.II.Pm.And.Qama. The criteria are most appropriate in the land units V4.I.Kbn.And.Qama, V4.I.Kbn.Kam.Qama, V4.I.Pm.And.Qama, V4.I.Pm.Kam.Qama, V4.I.Pm.Kam.Qast, V4.I.Sw.And.Qama. Criteria not permanently fit in units of land V1.V.HLKP.And.Qama, V1.V.HLKP.And.Qast, V2.IV.HLKP.And.Qama, V2.IV.HLKP.And.Qast, V2. IV.HLKS.And.Qast, V3.III.HLKP.And.Qama, V3.III.HLKS.And.Qama,

V3.III.HLKS.And.Qast, V4.II.HLKS.And.Qama. Spatial distribution of land suitability for criteria not suitable permanently scattered throughout all kanagarians in Sungai Pua sub-district except on Kanagarian Batagak. The suitability of the criteria land is very suitable and sufficiently suitable to spread across all kanagarians in Sungai Pua Subdistrict.
\end{abstract}

\section{Keywords: Conformity, Evaluation, Settlement}

Jurnal ini ditulis dari skripsi penulis dengan judul Evaluasi Kesesuaian Lahan Untuk Permukiman di Kecamatan Sungai Pua Kabupaten Agam untuk wisuda periode Maret 2018 


\section{PENDAHULUAN}

Pertumbuhan penduduk yang semakin meningkat dari tahun ke tahun menyebabkan meningkatnya kebutuhan akan rumah tinggal.

Peningkatan kebutuhan rumah tinggal tidak menutup kemungkinan berubahnya fungsi lahan-lahan pertanian, hutan dan kawasan lahan lainnya menjadi lahan permukiman baru. Sementara, pembangunan kawasan permukiman merupakan hal yang memerlukan perencanaan yang seksama. Perubahan lahan untuk permukiman merupakan hal yang terus terjadi hingga saat ini. Perubahan lahan untuk permukiman ini biasanya terjadi pada kawasan strategis (memiliki aksesibilitas yang baik) dan memiliki jumlah penduduk yang tinggi. Lahan untuk perumahan atau permukiman terletak pada kawasan budidaya di luar kawasan lindung yang mempunyai kriteriakriteria kemiringan lereng, curah hujan, daya dukung tanah, drainase, jenis tanah dan pada daerah yang labil (UU No. 24 Tahun 1992).

Lahan merupakan bagian dari bentangan alam yang mencakup pengertian lingkungan fisik termasuk iklim, topografi atau relief, hidrologi bahkan keadaan vegetasi alami (natural vegetation) yang semuanya secara potensial akan berpengaruh terhadap penggunaan lahan (FAO, 1976 dalam Rayes, 2007). Lahan merupakan sumberdaya yang sangat penting untuk memenuhi segala kebutuhan hidup, sehingga pengelolaannya harus dilakukan dengan hati-hati dan harus sesuai dengan kemampuannya agar tidak mengurangi nilai tata guna suatu lahan dan menurunkan produktivitas lahan.

Evaluasi lahan pada hakekatnya merupakan proses untuk menduga potensi lahan untuk

berbagai penggunaan, proses penilaian terhadap lahan untuk

dilakukan identifikasi kedalam bentuk kelas-kelas lahan. Tujuan evaluasi lahan adalah menyeleksi penggunaan lahan yang optimal untuk masing-masing satuan lahan tertentu dengan mempertimbangkan faktor fisik dan social ekonomi serta konservasi sumberdaya lingkungan untuk penggunaan yang lestari (Rayes, 2007).

Ritung S, dkk (2007:1) menyatakan kesesuaian lahan adalah tingkat kecocokan sebidang lahan untuk penggunaan tertentu. Kesesuaian lahan tersebut dapat dinilai untuk kondisi saat ini (kesesuaian lahan actual) atau setelah diadakan perbaikan (kesesuaian lahan potensial). Kesesuaian lahan actual adalah kesesuaian lahan berdasarkan data sifat biofisik tanah atau sumberdaya lahan sebelum lahan tersebut diberikan masukanmasukan yang diperlukan untuk mengatasi kendala. Kesesuaian lahan potensial menggambarkan kesesuaian lahan yang akan dicapai apabila dilakukan usaha-usaha perbaikan. 
Ahyuni (2013:35) mengatakan tujuan utama dari evaluasi kesesuaian lahan adalah untuk menduga tingkat kesesuaian dari suatu lahan untuk berbagai tipe penggunaan lahan. Kesesuaian lahan dibedakan atas 5 kelas dengan tingkatan sebagai berikut:

a. Kelas S1 = Sangat Sesuai (High Suitable), lahan tidak mempunyai faktor pembatas yang berarti/nyata terhadap penggunaan lahan tersebut secara berkelanjutan. Faktor pembatas yang ada umumnya hanya bersifat minor serta relatif tidak mempunyai produktivitas secara nyata,

b. Kelas $\mathrm{S} 2=$ Cukup Sesuai (Moderately Suitable), lahan yang memiliki faktor pembatas yang dapat berpengaruh terhadap produktivitas. Oleh karenaitudalamupaya pengelolaannya diperlukan tambahan masukan (input) yang relativesederhanauntuk meningkatkan produktivitas lahan tersebut,

c. Kelas S3 = Sesuai Marginal (Marginally Suitable), lahan mempunyai faktor pembatas yang cukup berat, sehingga faktor pembatas tersebut dapat sangat menurunkan tingkat produktivitasnya. Oleh karena itu diperlukan tambahan masukan (input) yang cukup tinggi untuk meningkatkan produktivitas lahan tersebut, d. Kelas N1 = Tidak Sesuai Saat Ini (Currently Not Suitable), lahan yang mempunyai faktor pembatas yang sangat berat, namun sifatnya tidak permanen.

Upaya perbaikan masih memungkinkan untuk dilakukan dengan menggunakan teknologi tinggi yang secara ekonomis dipandang masih layak,

e. Kelas N2 = Tidak Sesuai Permanen (Permanenty Not

Suitable), lahan yang mempunyai faktor pembatas yang sangat berat dan sifatnya sulit diatasi (cenderung permanen). Upaya perbaikan lahan tidak dapat dilaksanakan dengan menggunakan teknologi yang tersedia dan secara

ekonomis dipandang layak.

Evaluasi lahan permukiman pada hakekatnya merupakan proses untuk meningkatkan kesesuaian lahan untuk permukiman, dasar kerangka kerja dari evaluasi tingkat kesesuaian lahan adalah membandingkan karakteristik satuan lahan dengan persyaratan yang diperlukan untuk permukiman. Penentuan kriteria tingkat kesesuian lahan untuk permukiman dengan penentuan penilaian yang lebih spesifik bagi peruntukkan permukiman, mengikuti Karim (1997) seperti Tabel di bawah ini: 
Tabel 1. Tingkat Kesesuaian Lahan Untuk Permukiman

\begin{tabular}{|c|c|c|c|}
\hline No & Kelas & $\begin{array}{c}\text { Tingkat } \\
\text { Kesesuian } \\
\text { Lahan }\end{array}$ & Penilaian \\
\hline 1 & I & $\begin{array}{c}\text { Sangat sesuai } \\
\text { (SI) }\end{array}$ & $\begin{array}{c}\text { Satuan lahan sangat sesuai untuk } \\
\text { lokasi permukiman }\end{array}$ \\
\hline 2 & II & $\begin{array}{c}\text { Cukup Sesuai } \\
\text { (S2) }\end{array}$ & $\begin{array}{c}\text { Kondisi cukup sesuai untuk lokasi } \\
\text { permukiman atau dengan faktor } \\
\text { penghambat }\end{array}$ \\
\hline 3 & III & $\begin{array}{c}\text { Sesuai } \\
\text { Marginal(S3) }\end{array}$ & $\begin{array}{c}\text { Kondisi kurang baik untuk lokasi } \\
\text { permukiman dan banyak faktor } \\
\text { penghambat }\end{array}$ \\
\hline 4 & IV & $\begin{array}{c}\text { Tidak sesuai } \\
\text { sementara (N1) }\end{array}$ & $\begin{array}{c}\text { Kondisi yang buruk untuk } \\
\text { permukiman dan banyak faktor } \\
\text { penghambat. }\end{array}$ \\
\hline 5 & V & $\begin{array}{c}\text { Tidak sesuai } \\
\text { permanen(N2) }\end{array}$ & $\begin{array}{c}\text { Satuan lahan yang sangat buruk } \\
\text { untuk lokasi permukiman dan } \\
\text { banyaksekali faktor penghambat. }\end{array}$ \\
\hline
\end{tabular}

Sumber: Karim (1997)

Permukiman akan mengalami perkembangan yang selaras dengan pertumbuhan penduduk dan mempunyai pola-pola tertentu dan menciptakan bentuk struktur suatu kota yang berbeda dengan kota lainnya. Permukiman yang menempati areal paling luas dalam penataan ruang dibandingkan peruntukkan lainnya (Bintarto, 1989 dalam Koestoer, 2001). Permukiman adalah bagian dari lingkungan hidup di luar kawasan lindung, baik yang berupa kawasan perkotaan maupun pedesaan yang berfungsi sebagai lingkungan tempat tinggal atau lingkungan hunian dan tempat kegiatan yang mendukung perikehidupan dan penghidupan (UU RI nomor 4 tahun 1992).

Kecamatan Sungai Pua termasuk wilayah yang strategis karena berada pada koridor antara Kota Padang Panjang ataupun Pusat Kabupaten Agam (Lubuk Basung) dengan Kota Bukittinggi yang dilalui jalur jalan arteri, termasuk untuk koridor Agam-Bukittinggi berdasarkan kabijakan propinsi merupakan jalur yang diarahkan sebagai pengembangan kawasan wisata. Selain itu, Kecamatan Sungai Pua juga memiliki potensi-potensi alam yang dapat dikembangkan sebagai kawasan pariwisata, seperti; lokasinya diapit oleh Gunung Marapi dan Gunung Singgalang, terdapatnya potensi wisata air dan sebagainya.

Perkembangan yang terjadi di Kecamatan Sungai Pua terutama dalam pemanfaatan lahan untuk permukiman harus memperhatikan kondisi fisik alam lahan. Hal ini dimaksudkan agar perkembangan permukiman tidak menimbulkan permasalahan degradasi lingkungan di masa yang akan datang seiring dengan pertambahan penduduk yang membutuhkan lahan untuk beraktifitas. Jumlah penduduk akan terus bertambah sedangkan luas lahan tetap. Permasalahan tersebut dapat menimbulkan kerugian baik

material maupun non-material. Penempatan lokasi permukiman harus diselaraskan dengan kondisi kesesuaian lahan di Kecamatan Sungai Pua, dengan demikian kesinambungan lingkungan tetap terjaga dan dampak-dampak negatif yang dapat menimbulkan kerugian dalam jangka panjang dapat dihindarkan. Pemanfaatan lahan untuk permukiman perluu diatur dengan baik, sehingga sesuai dengan Rencana Tata Ruang Wilayah (RTRW) yang bersangkutan dengan mempertimbangkan aspek keseimbangan ekologis sehingga 
tidak sampai terjadi penurunan kualitas lahan.

Berdasarkan hal tersebut, penulis tertarik untuk mengangkat sebuah tema penelitian yaitu tentang evaluasi kesesuaian untuk permukiman di Kecamatan Sungai Pua Kabupaten Agam.

\section{METODE}

PENELITIAN

Berdasarkan latar belakang

permasalahan dan tujuan penelitian, maka penelitian ini tergolong jenis

penelitian deskriptif dengan pendekatan kuantitatif yang bertujuan untuk mengetahui karakteristik lahan dan kelas kesesuaian lahan.

\section{Teknik Pengumpulan Data}

Pengumpulan data dalam penelitian ini dilakukan dengan cara observasi lapangan dan pengambilan data pada instansi-instansi terkait. Adapun yang diobservasi adalah sebagai berikut:

\section{Karakteristik Lahan}

a. Kemiringan Lereng, yang didapatkan dari hasil ukur langsung dilapangan dengan menggunakan abney level sebagai alat pengukur kemiringan lereng. Semakin datar suatu lereng maka akan semakin baik untuk peruntukkan permukiman.

b. Kedalaman muka airtanah, yang didapat dari hasil ukur langsung di lapangan dengan cara mengukur kedalaman sumur penduduk setempat. Semakin dalam airtanah maka semakin baik untuk keawetan konstruksi rumah yang dapat dibangun.

c. Drainase, ditentukan di lapangan dengan melihat adanya gejala-gejala pengaruh air dalam penampang tanah. Mudah tidaknya air hilang dari tanah memerlukan kelas drainase tanah, air dapat hilang melalui permukaan tanah maupun melalui peresapan ke dalam tanah.

d. Lamanya genangan banjir, penelitian untuk lamanya genangan banjir didasarkan pada hasil pengamatan di lapangan dan wawancara dengan penduduk setempat.

e. Tekstur tanah, penentuan tekstur tanah di lapangan ditetapkan berdasarkan kepekaan indra perasa (kulit dari jempol dan telunjuk).

f. Singkapan batuan induk, didapat dengan cara menghitung persentasi luas daerah singkapan dengan luas daerah penelitian.

g. Kedalaman hamparan batuan dasar, cara pengukuran di lapangan dengan mengukur kedalaman tanah dari permukaan tanah sampai batuan dasar, mengukur dinding tebing, sungai dan sumur-sumur penduduk.

h. Sebaran bahan kasar, pengukuran diamati secara langsung di lapangan dengan 
cara menghitung perbandingan sebaran bahan kasar dengan luas permukaan tanah yang dinyatakan dalam persentase.

\section{Tingkat Kesesuaian Lahan Untuk Permukiman}

Teknik analisis data yang digunakan untuk menentukan tingkat kesesuaian lahan untuk permukiman yaitu:

a. Metode

pengharkatan

(scoring)

Pemberian nilai harkat masing-masing parameter adalah $1-5$, sehingga jumlah nilai harkat tertinggi yang mungkin diperoleh adalah 40 dan terendah adalah 8 . Nilai tertinggi mewakili kriteria yang sangat baik terhadap peruntukkan permukiman sebaliknya nilai rendah mewakili kriteria yang buruk atau tidak cocok terhadap peruntukkan permukiman.

b. Tumpang Susun (overlay)

Untuk membuat peta satuan bentuklahan yaitu dengan mengoverlay peta bentuklahan dengan peta kemiringan lereng, sedangkan untuk peta satuan lahan diperoleh dengan mengoverlay peta satuan bentuklahan, peta penggunaan lahan, peta kemiringan lereng, peta jenis tanah dan peta geologi.

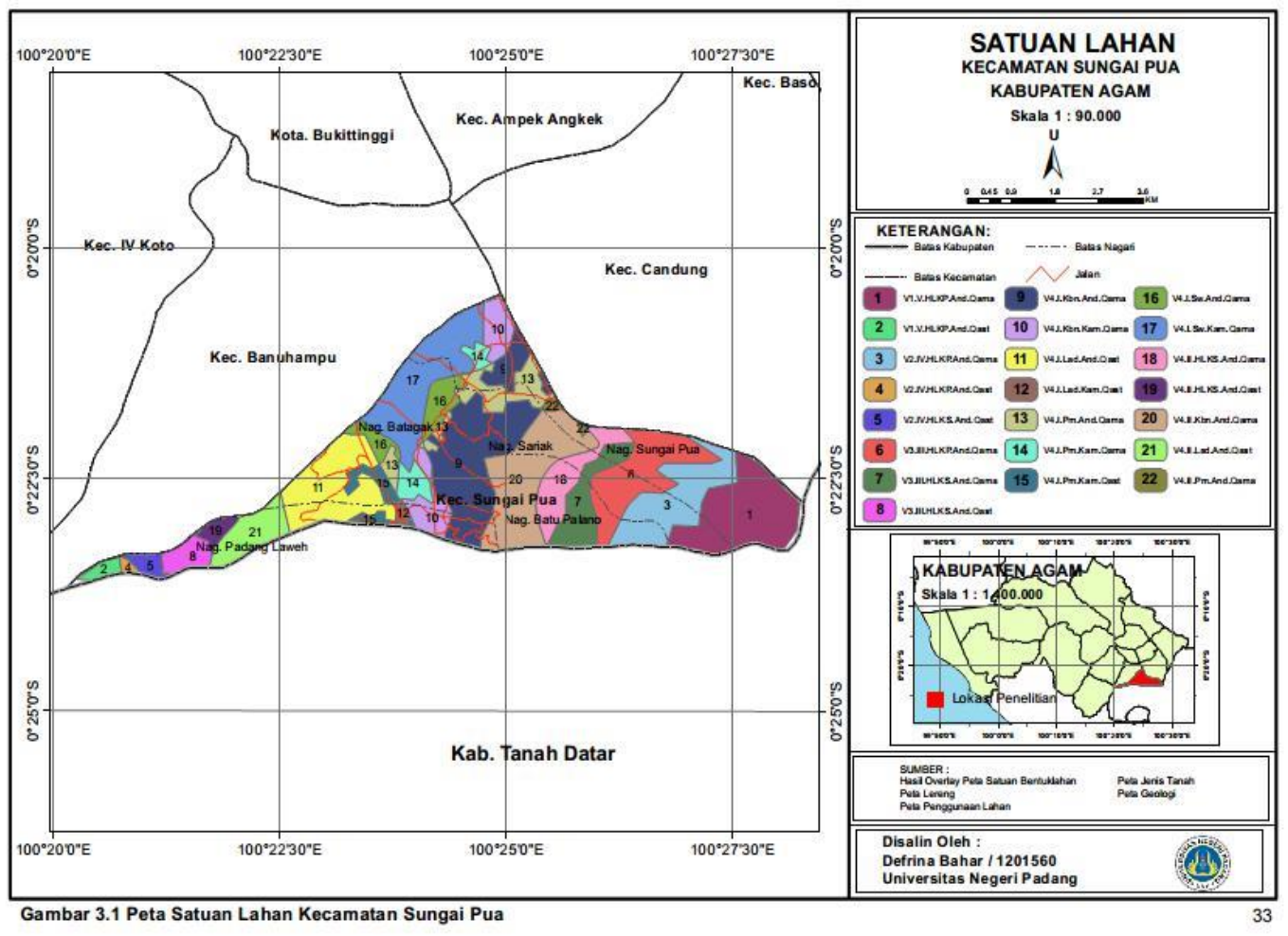

Gambar 1. Peta Satuan Lahan Kecamatan Sungai Pua 
HASIL PENELITIAN

DAN PEMBAHASAN

\section{Karakteristik Lahan}

Kecamatan Sungai Pua memiliki 22 jenis satuan lahan yang berbeda. Berdasarkan sampel yang dipilih, terdapat 13 satuan lahan pada kemiringan lereng datar sampai landai/bergelombang. Kecamatan Sungai Pua memiliki kriteria kesesuaian lahan yang beragam, dikategorikan menjadi tiga kriteria yaitu; sangat sesuai, cukup sesuai dan tidak sesuai permanen.

Berdasarkan observasi lapangan berikut hasil yang didapat pada masing-masing karakteristik lahan Kecamatan Sungai Pua, sebagai berikut:

1. Kemiringan lereng

Berdasarkan hasil penelitian kemiringan lereng, termasuk kategori sangat baik terdapat pada satuan lahan

V4.I.Lad.Kam.Qast, V4.I.Pm.And.Qama,V4.I.Pm.Ka m.Qast,V4.I.Sw.And.Qama,V4.I .Sw.Kam.Qama. Kategori baik terdapat pada satuan lahan V4.I.Kbn.And.Qama,V4.I.Kbn. Kam.Qama,V4.I.Lad.And.Qast, V4.I.Pm.Kam.Qama. Kategori sedang terdapat pada satuan lahan V4.II.HLKS.And.Qast, V4.II.Kbn.And.Qama,V4.II.Lad. And.Qast, V4.II.Pm.And.Qama.

2. Kedalaman muka airtanah Berdasarkan hasil penelitian untuk kedalaman muka airtanah pada Kecamatan Sungai Pua semua satuan lahan tergolong kategori sangat baik.

3. Drainase

Berdasarkan hasil penelitian daerah yang memiliki drainase baik yaitu pada satuan lahan V4.I.Kbn.And.Qama,V4.I.Kbn. Kam.Qama,V4.I.Pm.Kam.Qama ,V4.I.Sw.And.Qama,V4.II.Kbn. And.Qama. Kategori agak baik yaitu pada satuan lahan V4.II.Kbn.And.Qama, V4.I.Pm. And.Qama,V4.I.Pm.Kam.Qast,V 4.II.Pm.And.Qama. Kategori agak buruk terdapat pada satuan lahan V4.I.Sw.Kam.Qama, V4.II.HLKS.And.Qast,V4.II.Lad .And.Qast. Kategori buruk terdapat pada satuan lahan V4.I.Lad.Kam.Qast.

4. Lamanya genangan banjir Berdasarkan hasil penelitian, untuk kriteria lamanya genangan banjir untuk kategori tidak pernah terdapat pada satuan lahan V4.I.Kbn.And.Qama,V4.I.Kbn. Kam.Qama, V4.I.Lad.And.Qast, V4.I.Lad.Kam.Qast,V4.I.Pm.An d.Qama, V4.I.Pm.Kam.Qama, V4.I.Pm.Kam.Qast, V4.I.Sw.And .Qama, V4.II.HLKS.And.Qast, V4.II.Kbn.And.Qama,V4.II.Lad. And.Qast, V4.II.Pm.And.Qama.

Kategori kadang-kadang terdapat pada satuan lahan V4.I.Sw.Kam.Qama.

5. Tekstur tanah

Berdasarkan hasil penelitian maka diperoleh tanah dengan 
tekstur lempung berpasir dengan

kategori baik terdapat pada

satuan lahan

V4.I.Kbn.And.Qama,V4.I.Kbn.

Kam.Qama,V4.I.Pm.And.Qama,

V4.I.Pm.Kam.Qama. Tekstur

tanah dengan kategori sedang

terdapat pada satuan lahan

V4.I.Lad.And.Qast, V4.I.Pm.Ka

m.Qast,V4.I.Sw.And.Qama,

V4.I.Sw.Kam.Qama,V4.II.HLK

S.And.Qast,V4.II.Lad.And.Qast,

V4.II.Pm.And.Qama. Tekstur

tanah dengan kategori buruk

terdapat pada satuan lahan

V4.I.Lad.Kam.Qast dan

V4.II.Kbn.And.Qama.

6. Singkapan batuan induk

Berdasarkan hasil penelitian, wilayah yang tidak memiliki singkapan batuan induk terdapat pada satuan lahan V4.I.Kbn.Kam.Qama,V4.I.Lad. And.Qast,V4.I.Lad.Kam.Qast, V4.I.Pm.And.Qama,V4.I.Pm.Ka m.Qama,V4.I.Pm.Kam.Qast,V4. I.Sw.Kam.Qama,V4.II.HLKS.A nd.Qast,V4.II.Kbn.And.Qama, V4.II.Lad.And.Qast,V4.II.Pm.A nd.Qama. Wilayah yang memiliki sedikit singkapan batuan induk terdapat pada satuanlahanV4,I.Kbn.And.Qama dan V4.I.Sw.And.Qama.

7. Kedalaman hamparan batuan dasar

Pengukuran untuk kedalaman hamparan batuan dasar dengan kategori sangat baik terdapat pada satuan lahan
V4.I.Kbn.And.Qama,V4.I.Lad.A

nd.Qast, V4.I.Pm.And.Qama, V4.I.Pm.Kam.Qama,V4.I.Pm.Ka m.Qast, V4.I.Sw.And.Qama, V4.II.HLKS.And.Qast, V4.II.Kb n.And.Qama,V4.II.Lad.And.Qas t,V4.II.Pm.And.Qama.

Kedalaman hamparan batuan dengan kategori baik terdapat pada satuan lahan V4.I.Kbn.Kam.Qama,V4.I.Lad. Kam.Qast,V4.I.Sw.Kam.Qama.

8. Sebaran bahan kasar Berdasarkan hasil penelitian, sebaran bahan kasar dengan kategori sangat baik terdapat pada satuan lahan V4.I.Kbn.And.Qama,V4.I.Kbn. Kam.Qama, V4.I.Lad.Kam.Qast, V4.I.Pm.And.Qama,V4.I.Pm.Ka m.Qama, V4.I.Sw.Kam.Qama, V4.II.HLKS.And.Qast, V4.II.Kb n.And.Qama,V4.II.Lad.And.Qas t, V4.II.Pm.And.Qama. Sebaran bahan kasar dengan kategori baik terdapat pada satuan lahan V4.I.Lad.And.Qast, V4.I.Pm.Ka m.Qast dan V4.I.Sw.And.Qama

\section{Kesesuaian Lahan Permukiman}

\section{Sangat Sesuai}

Pada kriteria ini lahan tidak mempunyai faktor pembatas yang berarti/nyata terhadap penggunaan lahan permukiman secara berkelanjutan. Pada kriteria sangat sesuai pada

wilayah penelitian tidak ditemukan faktor pembatas yang berarti. 


\section{Cukup Sesuai}

Pada kriteria ini lahan memiliki faktor pembatas yang dapat

berpengaruh terhadap produktifitas. Pada wilayah penelitian, kriteria cukup sesuai memiliki beberap faktor pembatas yaitu; drainase, tekstur tanah dan kemiringan lereng. Pada kriteria ini lahan masih bisa dipakai untuk permukiman namun untuk mengatasi faktor pembatas tersebut memerluka biaya tambahan.

Berdasarkan hasil analisis yang telah dilakukan berdasarkan karakteristik lahan di daerah penelitian ditemukan 3 (tiga) kriteria kesesuaian lahan bagi peruntukkan permukiman, yaitu; tidak sesuai, cukup sesuai dan sangat sesuai. Kriteria tidak sesuai (N) terdapat pada 9 (sembilan) satuan lahan yang merupakan kawasan lindung, dengan luas $13,861 \mathrm{Km}^{2}$ atau $36,6373 \%$ dari keseluruhan area penelitian. Kriteria tidak sesuai tersebar di berbagai Kanagarian di Kecamatan Sungai Pua yaitu; Kanagarian Sungai Pua, Kanagarian Sariak, Kanagarian Batu
Palano dan sebagian kecil Kanagarian Padang Laweh. Kriteria cukup sesuai (S2) terdapat 7 (tujuh) satuan lahan dengan luas $12,603 \mathrm{Km}^{2}$ atau $33,3123 \%$ dari keseluruhan area penelitian. Kriteria cukup sesuai tersebar pada berbagai kanagarian di Kecamatan Sungai Pua yaitu; Padang Kudo, Padang Tajorok Kanagarian Batagak, Kanagarian Padang Laweh, Ateh Lubuak Limo Suku, Surau Baurek Limo Kampung, Panji Atas Limo Kampung Kanagarian Sungai Pua. Kriteria sangat sesuai (S1) terdapat 6 (enam) satuan lahan dengan luas $11,369 \mathrm{Km}^{2}$ atau $30,0504 \%$ dari keseluruhan area penelitian. Kriteria sangat sesuai tersebar pada berbagai kanagarian di Kecamatan Sungai Pua yaitu; Tabek Barawak, Lukok Limo Suku, Pincuran Badukuang, Kampung Durian Kanagarian Sungai Pua, Sungai Buluah Kanagarian Batagak, Sawah Dahulu Kanagarian Sariak. Untuk lebih jelasnya mengenai sebaran spasial kriteria kesesuaian lahan pada daerah penelitian dapat dilihat pada peta berikut ini: 


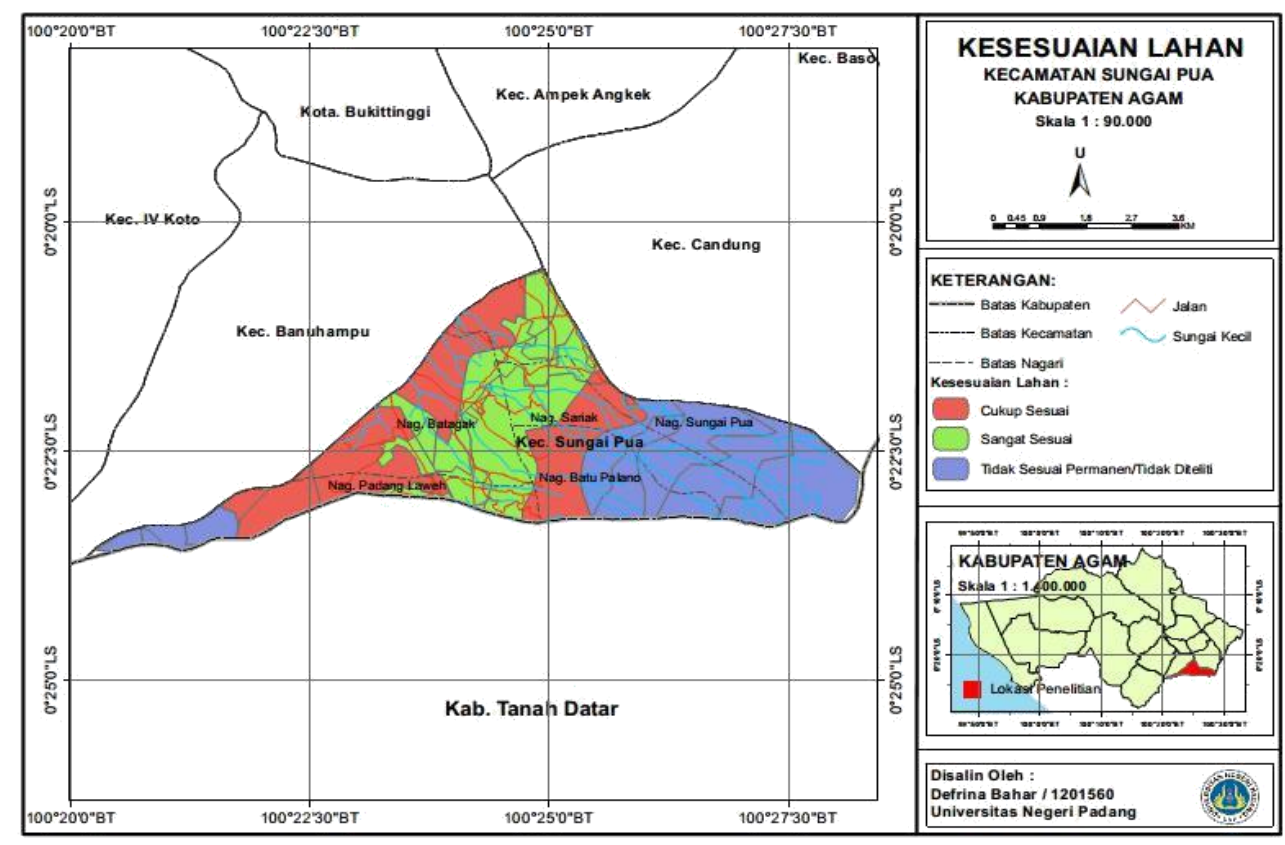

Gambar 4.9. Peta Kesesuaian Lahan Kecamatan Sungai Pua
Gambar 2. Peta Kesesuaian Lahan Untuk Permukiman Kecamatan Sungai Pua

\section{PEMBAHASAN}

Berdasarkan hasil penelitian ditemukan 3 (tiga) kelas kesesuaian lahan untuk permukiman, yaitu; tidak sesuai, cukup sesuai dan sangat sesuai. Kriteria tidak sesuai $(\mathrm{N})$ menunjukkan kondisi suatu lahan yang sangat buruk untuk lokasi permukiman dan banyak sekali faktor penghambat. Kriteria cukup sesuai (S2) menunjukkan kondisi suatu lahan yang cukup baik untuk lokasi permukiman atau dengan faktor penghambat. Kriteria sangat sesuai (S1) menunjukkan kondisi yang sangat sesuai untuk lokasi permukiman atau tanpa faktor pembatas.

Kriteria tidak sesuai atau tidak diteliti terdapat 9 (sembilan) satuan lahan yang memiliki luas 13,861
$\mathrm{Km}^{2}$ atau 36,6373 \% dari keseluruhan luas area penelitian. Pada wilayah penelitian, kriteria tidak sesuai ialah wilayah yang memiliki penggunaan lahan hutan, yang merupakan hutan lindung yang telah ditetapkan dalam RTRW (Rencana Tata Ruang Wilayah) Kabupaten Agam. Pada wilayah ini juga memiliki kemiringan lereng $>15 \%$. Kemiringan lereng ini juga menjadi faktor pembatas utama bagi nilai kesesuaian lahan untuk permukiman. Kriteria ini terdapat pada area hutan di perbukitan yang merupakan bagian administratif dari Kanagarian Sungai Pua, Kanagarian Sariak, Kanagarian Batu Palano dan Kanagarian Padang Laweh.

Kriteria cukup sesuai (S2) terdapat pada 7 (tujuh) satuan lahan 
dengan luas $12,603 \mathrm{Km}^{2}$ atau $33,3123 \%$ dari luas area penelitian. Pada kriteria ini menunjukkan kondisi yang cukup sesuai bagi peruntukkan permukiman meski masih memiliki faktor pembatas namun tidak memberi pengaruh yang berarti bagi peruntukkan permukiman. Beberapa faktor pembatas tersebut antara lain; kemiringan lereng, tekstur tanah, drainase dan banjir. Dalam upaya

pembangunan perumahan atau permukiman pada wilayah ini tidak akan memberikan resiko buruk, serta tidak membutuhkan persyaratan teknis tertentu.

Selanjutnya, wilayah yang memiliki kriteria sangat sesuai (S1) terdapat 6 (enam) satuan lahan pada wilayah penelitian dengan luas $11,369 \mathrm{Km}^{2}$ atau $30,0504 \%$ dari keseluruhan area penelitian. Analisis yang telah dilakukan berdasarkan karakteristik lahan pada wilayah ini memiliki nilai kesesuaian yang sangat sesuai untuk permukiman.

\section{PENUTUP}

\section{Kesimpulan}

Berdasarkan hasil penelitian yang telah dibahas sebelumnya, dapat dijabarkan kesimpulan penelitian yaitu:

a. Berdasarkan 8 (delapan) karakteristik lahan yaitu; kemiringan lereng, kedalaman muka airtanah, drainase, lamanya genangan banjir, tekstur tanah, singkapan batuan, kedalaman hamparan batuan dasar dan sebaran bahan kasar setiap satuan lahan memiliki karakteristik yang berbedabeda. Ada karakteristik yang mendukung untuk dikembangkannya

permukiman, ada karakteristik yang menjadi penghalang atau membatasi perkembangan permukiman atau lebih dikenal dengan variabel pembatas.

b. Tingkat kesesuaian lahan untuk permukiman pada daerah penelitian ditemukan 3 (tiga) kriteria kesesuaian lahan, yaitu; tidak sesuai, cukup sesuai dan sangat sesuai. Dalam hal ini, untuk kriteria untuk kriteria tidak sesuai ialah terdapat 9 (sembilan) satuan lahan dengan luas $13,861 \mathrm{Km}^{2}$ atau $36,6373 \%$ dari keseluruhan area penelitian. Kriteria cukup sesuai terdapat 7 (tujuh) satuan lahan dengan luas $12,603 \mathrm{Km}^{2}$ atau $33,3123 \%$ dari keseluruhan area penelitian. Kriteria sangat sesuai terdapat 6 (enam) satuan lahan dengan luas $11,369 \mathrm{Km}^{2}$ atau $30,0504 \%$ dari keseluruhan area penelitian.

\section{Saran}

a. Saran Bagi Masyarakat atau
Pengembang Permukiman 
1) Faktor

pembatas

kemiringan

sebaiknya

lereng,

permukiman disarankan

pada area dengan

kemiringan lereng $0 \%$

sampai $15 \%$ untuk

menghindari berbagai

ancaman bahaya longsor

dan semacamnya. Selain

itu, membangun

permukiman pada area dengan kemiringan lereng $>15 \%$ juga akan menelan biaya yang lebih tinggi dalam konstruksi, seperti biaya perataan lahan dan sebagainya,

2) Faktor pembatas drainase, telah diketahui bahwa mudah atau tidaknya air hilang dari tanah menentukan kelas drainase tanah, jika kondisi drainase buruk maka kecendrungan air tergenang tentu lebih besar hal tersebut juga akan memunculkan anacaman banjir atau genangan.

b. Saran Bagi Pemerintah

Daerah

Sebagai pemangku kebijakan pemerintah daerah sepatutnya lebih fokus dalam menangani berbagai permasalahan permukiman yang terjadi, baik dari segi perijinan terhadap pembangunan perumahan baru maupun dalam menangani masalahmasalah lain,

c. Saran Bagi Peneliti Lain

Penelitian ini mungkin saja masih memiliki kekurangan, namun tentunya dapat menjadi salah satu rujukan bagi penelitian selanjutnya. Tentunya penelitian ini dapat menjadi penelitian rujukan bagipenelitiansejenis.

Adanya penilaian dari berbagai aspek lainnya,

seperti dari aspek kebencanaan, aksesibilitas, sarana prasarana dan lain sebagainya,tentunya penelitian dapat saling menyempurnakan.

\section{DAFTAR PUSTAKA}

Ahyuni. 2013. Perencanaan Penggunaan Lahan. Padang: Jurusan Geografi Fakultas Ilmu-Ilmu Sosial Universitas Negeri Padang.

Karim, Sutarman. 1997. Evaluasi Medan Untuk Permukiman di Kotamadya Padang Propinsi Sumatera Barat.

Yogyakarta:UGM.

Koestoer, Raldi Hendro. 2001. Dimensi Keruangan Kota, Teori dan Kasus. Jakarta: UI Press.

Rayes, Luthfi. 2007. Metode Inventarisasi Sumber Daya Lahan. Yogyakarta: Andi.

Ritung S, dkk. 2007. Panduan Evaluasi Kesesuaian Lahan 
dengan Contoh Peta Arahan

Penggunaaan Lahan

Kabupaten Aceh Barat. Bogor:

Balai Penelitian Tanah dan
World Agroforestry Centre (ICRAF).

Undang-Undang Republik Indonesia Nomor 4 tahun 1992 tentang

Perumahan dan Permukiman. 